\title{
In Memory of Prof. Yehia El-Gamal
}

With great sorrow, the editorial team of the Egyptian Journal of Pediatric Allergy and Immunology announce the sad demise of Professor Yehia El-Gamal, the Editor-in Chief, who passed away, on Saturday March 6, 2021.

Prof. El-Gamal established the specialty of Pediatric Allergy and Immunology in Egypt and the Middle East and founded the first specialized unit in this specialty in 1988 which has been accredited as a WAO International Center of Excellence since 2018. Prof. El-Gamal chaired the Department of Pediatrics, Ain Shams University from 1997 till 2001. He founded the Egyptian Society of Pediatric Allergy and Immunology (ESPAI) in 2002 which produces this journal since 2003.

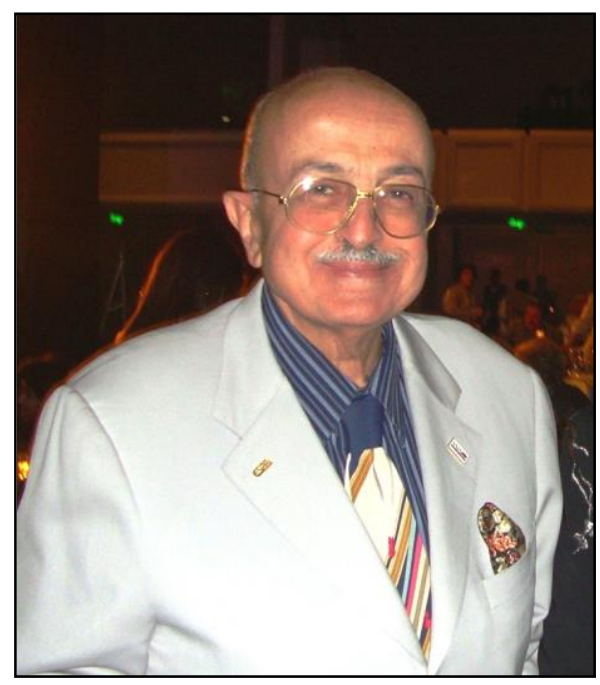
With his devotion and tremendous efforts, the journal became acknowledged by the Egyptian Knowledge Bank (EKB) and has become indexed in the Web of Science (Clarivate) since 2019. It is, therefore, considered an international publication by the Supreme Councils of Egyptian Universities.

Prof. El-Gamal received many prestigious awards including the State Merit Prize in Medicine (2014), the National First-Degree Golden Medal for Science and Art, the Discretionary Award of Ain Shams University (2011) and Egypt's 1st Degree Golden Medal for Science and Art in 2016. He was also granted the WAO Distinguished International Service Award in 2011 and the ACAAI Distinguished International Fellow Award in 2009. He was granted with a group of researchers the Elsevier Atlas Award 2017. The Egyptian Academy of Scientific Research and Technology grants a 15,000 Egyptian pound distinction award carrying his name yearly since 1989 and he was granted the title of Ideal Medical Educator by the Egyptian Medical Syndicate in 1995.

As a known international figure, Prof. Yehia El-Gamal was member of the World Allergy Organization (WAO) Board of Directors (2007 - 2011) and Chair of the WAO Bylaws Committee and Co-Chair of its Ethics Committee. He was a Fellow of the American Academy of Allergy, Asthma and Immunology (AAAAI) since 1992 and chaired its Middle East and Africa Region Committee (2008 - 2011). He was also member of the European Academy of Allergy and Clinical Immunology (EAACI) since 2001 and fellow of the American College of Allergy, Asthma and Immunology (ACAAI) since 2007. He was instrumental in founding the Pan-Arab Society of Allergy, Asthma and Immunology (PASAAI) in 2019. He served as member of the Technical Advisory Group (TAG) of the World Health Organization (WHO) for polio eradication.

His Scopus h-index is 23 which reflects citations from 145 publications in international, regional, and national periodicals and is member of the editorial board and regular reviewer of many national and international journals and he authored and co-authored chapters in several books including the World Allergy Organization White Book in Allergy. Supervised $30 \mathrm{PhD}$ and 103 Masters' theses in pediatrics and Allergy/Immunology and he participated in 167 international, regional, and local congresses and scientific meetings.

As a mentor and leader, Prof El-Gamal was always a great gift, gracious and wonderful professor, true gentleman, and a kind benevolent father to all of us. We do pay tribute to such a great physician and educator.

We are truly saddened by his demise and do miss his sincere mentorship and support but will do our very best to ensure that his legacy stays alive.

The Editorial Board 